\title{
Life in (and out of) the lagoon: fine-scale movements of green turtles tracked using time-depth recorders
}

\author{
J. M. Blumenthal ${ }^{1,2, *}$, T. J. Austin ${ }^{1}$, J. B. Bothwell ${ }^{1}$, A. C. Broderick ${ }^{2}$, G. Ebanks-Petrie ${ }^{1}$, \\ J. R. Olynik ${ }^{1}$, M. F. Orr ${ }^{1}$, J. L. Solomon ${ }^{1}$, M. J. Witt ${ }^{2}$, B. J. Godley ${ }^{2}$ \\ ${ }^{1}$ Cayman Islands Department of Environment, Box 486, Grand Cayman KY1-1106, Cayman Islands \\ ${ }^{2}$ Centre for Ecology and Conservation, School of Biosciences, University of Exeter Cornwall Campus, Penryn TR10 9EZ, UK
}

\begin{abstract}
Tracking fine-scale movements in relation to threats is fundamental to the management of exploited marine species, yet there is considerable difficulty associated with gathering such data at sea. By combining a capture-recapture study with deployment of time-depth recorders (TDRs) and ultrasonic tags, we elucidated distribution and daily movements of juvenile green turtles Chelonia mydas exposed to a legal marine turtle fishery in the Cayman Islands. For instrumented turtles, distinct diel activity patterns were observed: dives during the day were shorter and more active than those at night, implying diurnal foraging and nocturnal resting. Spatially, while capture and recapture locations suggested fidelity to a shallow lagoon, when turtles were fitted with TDRs and ultrasonic tags we demonstrated that they regularly moved out of the lagoon and onto the reef, where they could legally be captured in the marine turtle fishery. Our results are thus novel and valuable in a management context in that we demonstrated that seemingly protected aggregations of juvenile green turtles within a lagoon were, in fact, exposed to legal capture on a near-daily basis. This emphasizes the importance of assessing diel activity patterns of juvenile marine turtles, particularly with respect to directed take and other threats.
\end{abstract}

KEY WORDS: Green turtle $\cdot$ Chelonia mydas $\cdot$ Spatial ecology $\cdot$ Seagrass $\cdot$ Coral reef $\cdot$ Time-depth recorder $\cdot$ TDR Resale or republication not permitted without written consent of the publisher

\section{INTRODUCTION}

Due to spatial variability in intensity of threats, tracking movement is fundamental to the management of endangered animals (Cooke 2008, Bograd et al. 2010). As commercially valuable migratory species which often overlap in distribution with fisheries, marine turtles are susceptible to directed and incidental harvest throughout their range (Lewison et al. 2004). It is well established that impacts of fishery-related mortality cross geopolitical boundaries; for example, green turtles originating from both regionally important (Tortuguero, Costa Rica; Troëng et al. 2005) and critically reduced (Cayman Islands; Blumenthal et al. 2006) rookeries migrate to foraging grounds in Nicaragua, where a commercial turtle fishery persists (Campbell \& Lagueux 2005). However, in addition to tracking transboundary migrations, characterization of fine-scale movements (e.g. with respect to the boundaries of local marine protected areas) has key implications for marine turtle management, as has been demonstrated in adult loggerheads (Schofield et al. 2007, Zbinden et al. 2007). For juvenile green turtles, while individuals on foraging grounds are known to make daily movements from foraging to resting sites (Mendonca 1983, Ogden et al. 1983), few studies have investigated how local movements determine vulnerability to anthropogenic threats.

Deployment of remote systems such as satellite transmitters (see Godley et al. 2008 for review) and light geolocation system tags (Storch 2003, Fuller et al. 2008) has been extremely effective in tracking longrange migrations of marine turtles, but location resolution of these instruments is generally insufficient to characterize fine-scale patterns of movement of resi- 
dent animals. On foraging grounds, long-established techniques such as in-water capture and flipper tagging have proven essential in establishing survivorship (Bjorndal et al. 2003a) and growth rates (Balazs \& Chaloupka 2004, Chaloupka et al. 2004), but such methods are limited in their ability to elucidate diel movements between capture and recapture. Recently, radio and ultrasonic tracking (e.g. van Dam \& Diez 1998, Seminoff et al. 2002, Taquet et al. 2006) and deployment of GPS loggers (Schofield et al. 2007) and Argos satellite-linked GPS tags (Schofield et al. 2009) has proven useful in unveiling local movements, and determination of movements via dead reckoning represents a promising emerging technology (Wilson et al. 2008). However, these methods are relatively resource- and/or time-intensive.

Time-depth recorders (TDRs) represent cost-effective and widely utilized instruments in marine turtle research (e.g. van Dam \& Diez 1996, Hays et al. 2000, Ropert-Coudert et al. 2009), but lack a spatial context (i.e. depth but not location is recorded). In the Cayman Islands, drastic differences in bathymetry inside and outside a lagoon (sheltered area within a barrier reef) provide opportunities to infer locations of dives from depth profiles. In the present study, integration of TDR recordings with bathymetric data allowed us to determine location of instrumented turtles (inside or outside the lagoon), opening up the possibility of using TDRs to examine daily movements of juvenile green turtles and their resultant exposure to anthropogenic threats.

Turtle fishing in the Cayman Islands began shortly after European discovery (in 1503) and played an important role in shaping the economy and culture (Bell et al. 2006). However, due to heavy exploitation, nesting populations collapsed by the early 1800s (Lewis 1940). While rookeries are still critically reduced (Bell et al. 2007), a low-level legal fishery persists to this day (Bell et al. 2006). Since 1985, the fishery has been regulated through legislation licensing traditional fishers and setting quotas (Cayman Islands Government 1985), and harvest is well-monitored, with a requirement for fisheries officers to measure and document all captured turtles (Richardson et al. 2006). However, from 1985 to 2008, minimum size limits (protecting smaller green turtles and allowing only animals $>54 \mathrm{~kg}$ to be taken) focused legal exploitation on larger individuals, including reproductive adults (Bell et al. 2006). In 2008, fishery size limits were revised in order to protect reproductively valuable subadult and adult turtles (Cayman Islands Government 2008); a ban was instituted on taking green turtles $>60 \mathrm{~cm}$ (and also $<40 \mathrm{~cm}$ ) curved carapace length (CCL), where CCL of reproductive females on Cayman Islands nesting beaches is $>100 \mathrm{~cm}$ (Cayman Islands Department of Environment unpubl. data). Thus, larger and smaller size classes are now protected, and juvenile green turtles from 40 to $60 \mathrm{~cm}$ CCL are vulnerable to legal exploitation in the Cayman Islands for the first time in more than 20 yr.

In addition to setting size limits and quotas, Cayman Islands turtle fishery licensing conditions establish geographic areas open to fishing. As turtles are protected within lagoons and exposed to legal take in some adjacent areas (Bell et al. 2006), habitat use and daily movements determine exposure to fisheryrelated threats. Thus, deployment of TDRs and ultrasonic tags on green turtles of legal size for capture in the marine turtle fishery allowed us to assess vulnerability and management requirements for an aggregation of juvenile green turtles in a Caribbean coastal ecosystem.

\section{MATERIALS AND METHODS}

In the Grand Cayman South Sound lagoon (Fig. 1), juvenile green turtles were captured using the turtle rodeo method (Limpus \& Reed 1985), wherein animals were pursued in a small boat and caught at the surface of the water by a researcher diving from the bow. In an

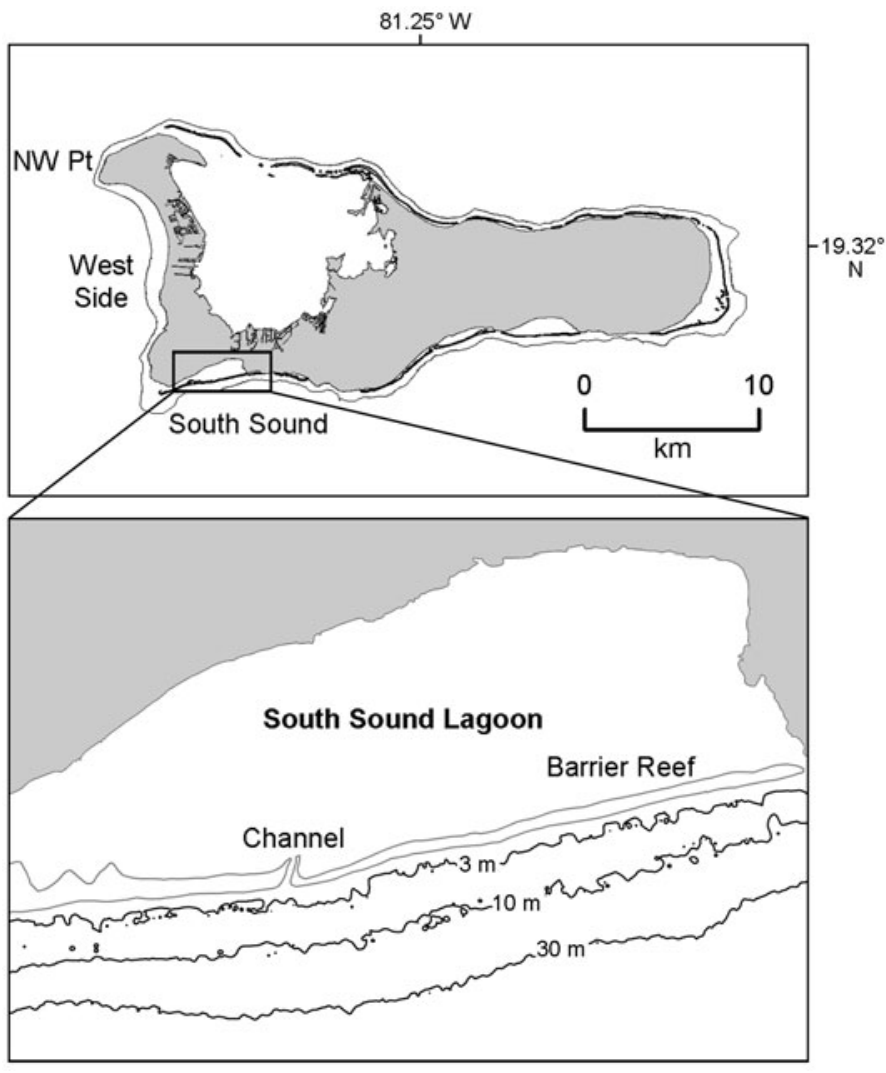

Fig. 1. South Sound, West Side and North West Point (NW Pt), Grand Cayman. Lower panel depicts 3,10 and $30 \mathrm{~m}$ depth contours for the South Sound study area 
effective modification to this technique, smaller turtles were pursued until they surfaced to breathe and then scooped out of the water with large long-handled nets (Aquatic Eco-Systems, part no. LN22). In order to reduce potential stress, no more than 3 attempts were made at capturing an individual using either methodology. In addition to rodeo capture in South Sound, green turtles were opportunistically hand-captured in western Grand Cayman (Fig. 1) when encountered during in-water surveys of hawksbill turtles (Blumenthal et al. 2009a).

Turtles were sighted from a small vessel and, although the search pattern was not truly random, the whole the lagoon was searched during the course of every survey bout. For each sighting, turtle habitat and GPS location were recorded. Measurements of mass, straight carapace length (SCL) and CCL (taken from the center of the nuchal notch to the posterior-most marginal scute) were recorded for all captured turtles and used to determine size distribution and calculate growth rate (Bjorndal \& Bolten 1988). In order to allow individual identification, turtles were tagged with passive integrated transponder (PIT) tags and double inconel flipper tags (Blumenthal et al. 2009a). Additionally, a white grease pen was used to apply a temporary mark to the carapace of each turtle, preventing individuals from being caught more than once per capture occasion.

In November 2006, TDRs (LTD1110, Lotek) and ultrasonic tags (V13, VEMCO) were deployed on 6 green turtles captured in the South Sound lagoon. Instrument housings were constructed from Starboard polyethylene, with holes in the lids and sides of the housings to facilitate pressure equilibration for TDRs and transmission of signals from ultrasonic tags (Blumenthal et al. 2009b). To prepare for housing attachment, a rear lateral scute on each turtle was scrubbed, sanded and degreased with acetone, and housings were attached with 2-part epoxy. Turtles were released at the site of capture (confirmed by GPS). TDRs recorded depth and temperature at $10 \mathrm{~s}$ intervals for an $8 \mathrm{~d}$ period (depth accuracy: $\pm 0.5 \mathrm{~m}_{i}$ temperature accuracy: $\pm 0.3^{\circ} \mathrm{C}$ ).

A VEMCO VR100 receiver with directional and omni-directional hydrophones was used to locate instrumented turtles. Following recapture, housings were removed and TDRs were subsequently downloaded using manufacturer software (TagTalk 1100, Lotek). After conversion of TDR pressure data to depth (taking the density of saltwater as $1.03 \mathrm{~g} \mathrm{~cm}^{-3}$ ), dive analysis software (MultiTrace MT-Dive, Jensen Software) was used to compute descriptive statistics (presented as means $\pm \mathrm{SD}$ ) for individual dives-i.e. duration and depth of the bottom phase of the dive (portion of the dive between points of inflection)-and the coefficient of variation (CV) of the depth of the bottom phase was calculated to evaluate activity level (Blumenthal et al. 2009b).

To determine movements, ArcView v.9.2 (ESRI) was used to overlay bathymetric contours (derived from single beam sonar, Cayman Islands Government unpubl. data) on a map of the study area, indicating that depths $>3 \mathrm{~m}$ represented habitats outside the lagoon (Fig. 1). Thus, turtle location (inside or outside the protected lagoon) could be inferred based on dive depths and confirmed by ultrasonic tracking and direct observation.

Date- and location-specific sunrise and sunset times were obtained from the US Naval Observatory Astronomical Applications Department (http://aa.usno.navy. mil) in order to investigate diel patterns in diving behavior. To achieve normal distributions for the variables of dive depth, duration and $\mathrm{CV}$, the following transformations were applied: $\log \{-\log [1-($ Depth/100) $]\}$, $\log ($ Duration +1$)$ and sqrt(CV). Then, using GenStat (11th edn), 3 linear mixed effects models (restricted maximum likelihood method) were constructed: (1) nocturnal versus diurnal dive depth; (2) nocturnal versus diurnal dive duration; and (3) nocturnal versus diurnal CV. Models included all dives, with individual turtle incorporated as a random effect in order to control for the effect of each individual and thus avoid pseudoreplication.

\section{RESULTS}

\section{Capture data}

Of 66 individual turtles tagged, 10 were recaptured on one occasion and one was recaptured on 2 occasions. The mean CCL for all captured turtles was 55.7 $\pm 11.5 \mathrm{~cm}$, with a range of 32.8 to $80.7 \mathrm{~cm}$. All 6 instrumented turtles were of legal size for capture under marine turtle fishery regulations: mean CCL was 52.9 $\pm 6.8 \mathrm{~cm}$, with a range of 40.6 to $59.0 \mathrm{~cm}$ (Fig. 2).

In South Sound, all captures took place on shallow seagrass beds within the lagoon, with $85 \%$ of captures and sightings occurring within $500 \mathrm{~m}$ of a channel from the lagoon to the reef (Fig. 3a). For turtles tagged and recaptured in South Sound, mean time at large $(\mathrm{n}=10$ turtles) was $527 \pm 212 \mathrm{~d}$, with a range of 173 to $853 \mathrm{~d}$. One green turtle initially captured in western Grand Cayman was recaptured $>2$ yr later in South Sound. Another individual had a titanium flipper tag from the Cayman Turtle Farm, indicating that the animal had been hatched and reared in captivity for approximately 8 mo. This captive-bred animal was released at North West Point, Grand Cayman, and was captured in South Sound after $7.2 \mathrm{yr}$ in the wild. 


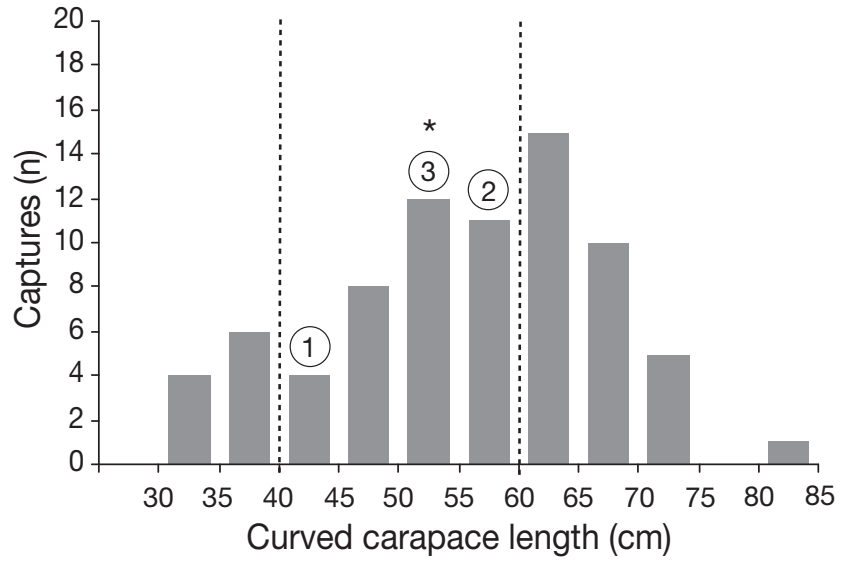

Fig. 2. Chelonia mydas. Size distribution (curved carapace length) for instrumented green turtles $(O$, no. of turtles in each size class is given within the circles, $\mathrm{n}=6$ ) in comparison with size distribution of all captured green turtles (bars). *: an instrumented individual which was not recovered. Dotted lines show minimum and maximum size limits for capture in the legal marine turtle fishery
Mean growth rate was $4.1 \pm 2.2 \mathrm{~cm} \mathrm{yr}^{-1}$, with a range 0.5 to $7.5 \mathrm{~cm} \mathrm{yr}^{-1}(\mathrm{n}=11$, increments of $>170 \mathrm{~d})$. For the captive-bred turtle, size at recapture was $75.5 \mathrm{~cm}$ SCL and $62.5 \mathrm{~kg}$. As size at release from the Cayman Turtle Farm averages $29 \mathrm{~cm}$ SCL and $3.6 \mathrm{~kg}$ (Wood \& Wood 1993, Bjorndal et al. 2003b), this suggests a mean growth rate of $6.4 \mathrm{~cm} \mathrm{yr}^{-1}$.

Despite the shallow nature of much of the study area, use of ultrasonic tags greatly facilitated TDR recovery. The recapture rate for instrumented turtles was $>80 \%$ (5 of 6 TDRs were retrieved) in comparison with a recapture rate of $<17 \%$ for un-instrumented turtles in the South Sound capture-recapture study.

\section{Movements}

The majority of captures in the capture-recapture study occurred in close proximity to a narrow manmade boat channel through the barrier reef (Fig. 3a)

a
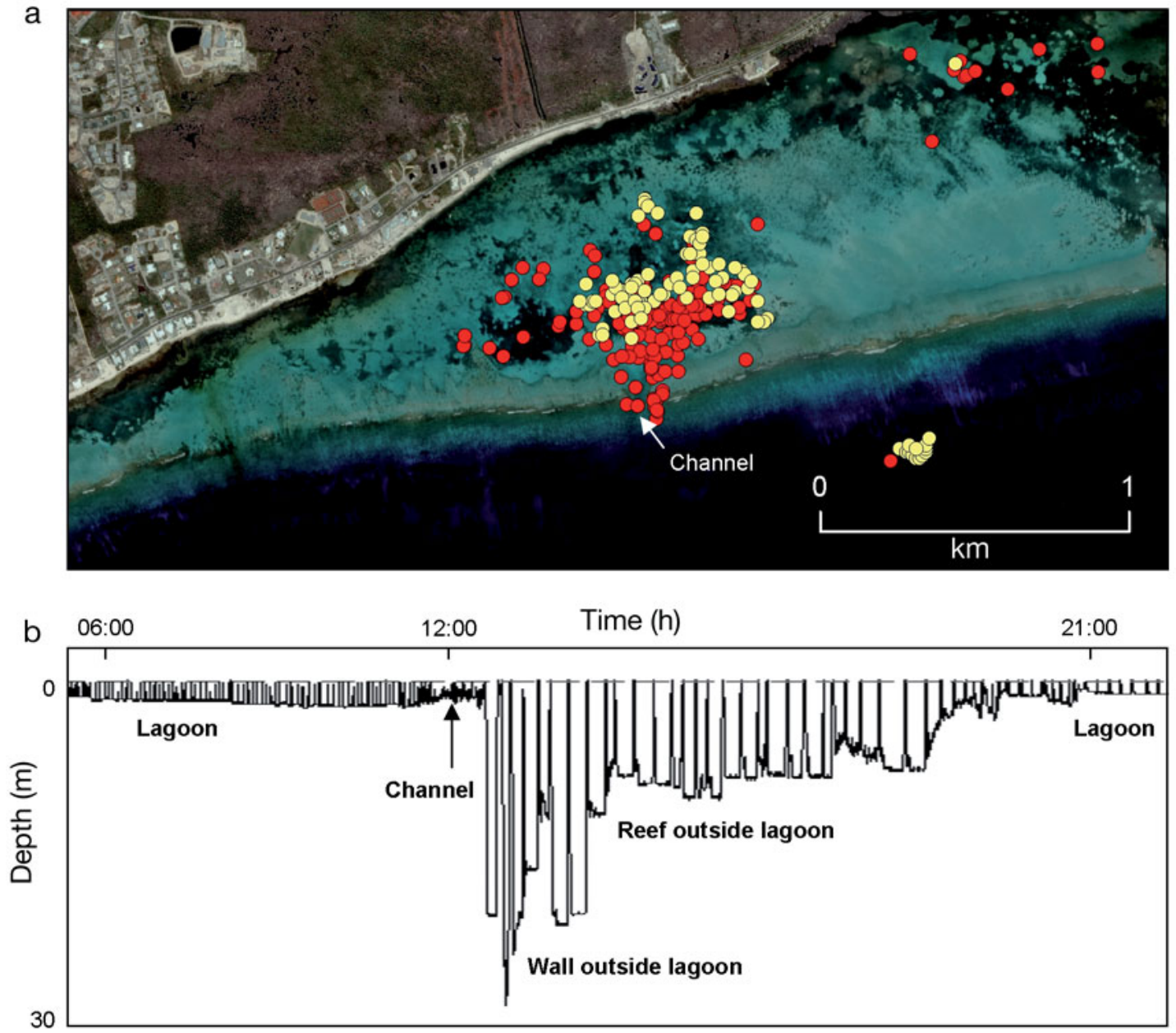

Fig. 3. Chelonia mydas. (a) Sighting and capture points (red circles) and ultrasonic detections (yellow circles) for green turtles in the South Sound lagoon. Captures clustered in a high-use area between a channel and a public boat launching ramp, but one instrumented turtle was sighted and detected outside the lagoon. (b) Time-depth recorder depth data suggest diverse habitat utilization within $(<3 \mathrm{~m})$ and outside the lagoon $(>3 \mathrm{~m})$ 
and, when pursued during capture bouts, turtles often escaped through the channel into deeper waters. It was possible to infer turtle location from dive profiles (Fig. 3b) as, based on bathymetry for the study area, dives to depths $>3 \mathrm{~m}$ must have occurred outside the lagoon. By examining dive depths, we determined that instrumented turtles regularly left their presumed habitat of the seagrass bed (where depths do not exceed $3 \mathrm{~m}$ ) and traveled to the reef (maximum recorded dive depth $28 \mathrm{~m}$ ).

Movement of instrumented turtles from the lagoon to the reef outside the lagoon was confirmed by ultrasonic tracking $(\mathrm{n}=98$ detections; Fig. 3a) and direct observation: one instrumented individual was detected and sighted outside the lagoon in $21 \mathrm{~m}$ of water, swimming along the bottom in coral reef habitat. This determination of movement from the lagoon to the reef was also supported when dive depths and sea temperatures were considered in concert; within the lagoon,

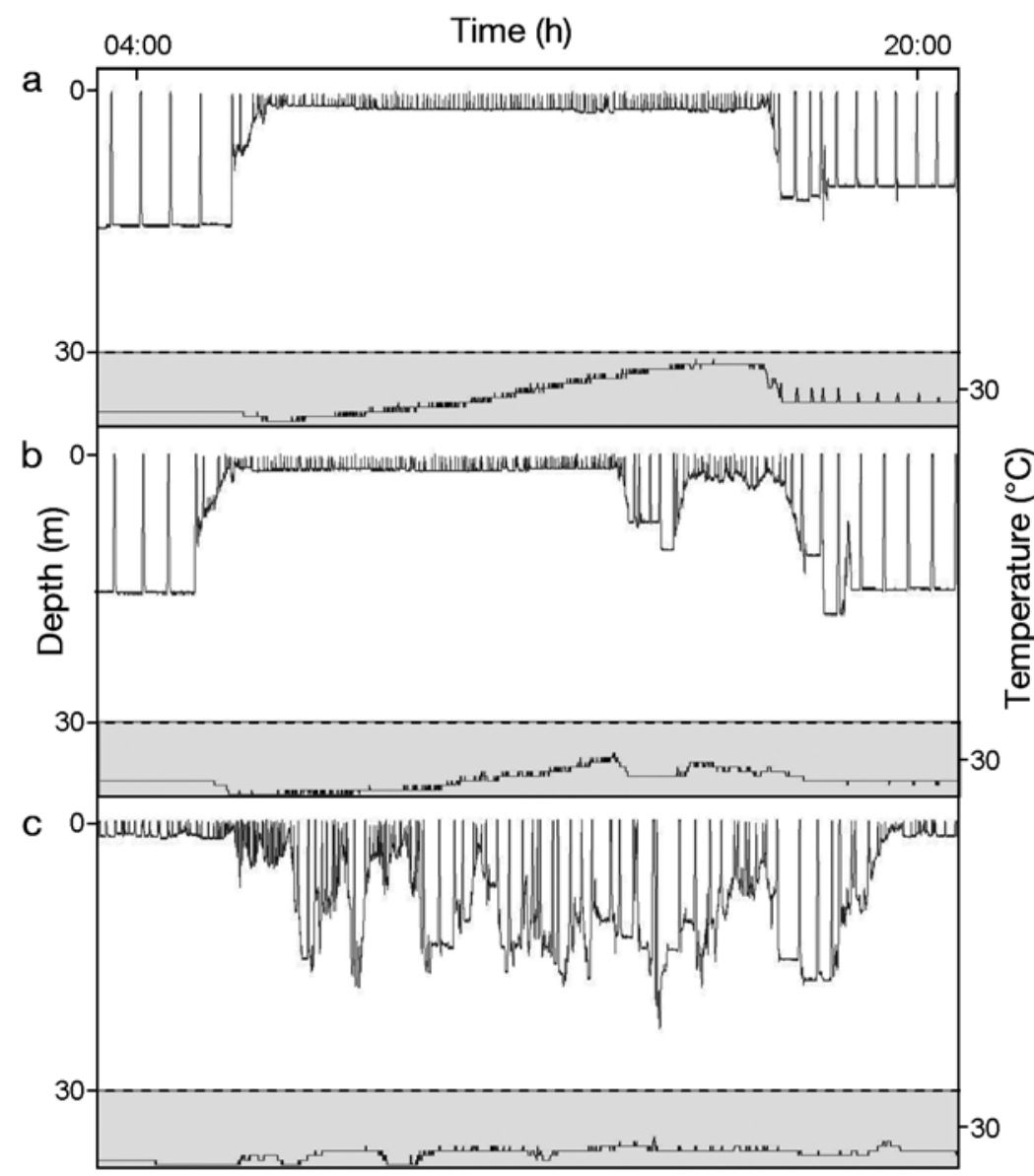

Fig. 4. Chelonia mydas. Selected daily profiles of depth (white background) and temperature (gray background) recorded by time-depth recorders (a) inside the lagoon during the day (outside the lagoon at night); (b) inside the lagoon during the day with an excursion to the reef in the afternoon (outside the lagoon at night); and (c) outside the lagoon during the day (inside the lagoon at night) temperatures increased steadily throughout the day (Fig. 4a), a drop in temperature was evident when turtles moved from lagoon to reef (Fig. 4b), and temperatures remained relatively constant outside the lagoon (Fig. 4c). Finally, photos obtained from underwater photographers confirm the presence of green turtles on the reef in habitats including hard-bottom, coral reef and reef wall (vertical drop-off/slope edge) (Fig. 5).

For instrumented turtles ( $\mathrm{n}=5$ for which TDRs were recovered), mean dive duration was $3.8 \pm 0.7 \mathrm{~min}$ for diurnal dives and $11.9 \pm 8.3 \mathrm{~min}$ for nocturnal dives; dive depth was $2.1 \pm 0.4 \mathrm{~m}$ for diurnal dives and $4.7 \pm$ $5.1 \mathrm{~m}$ for nocturnal dives (Table 1). The CV of the depth of the bottom phase of the dive (examined to evaluate activity level) was $0.16 \pm 0.01$ for dives during the day and $0.13 \pm 0.03$ for dives at night ( $\mathrm{n}=5$ ind.). Thus, dives during daylight hours were shorter than those at night (mixed effects model, Wald statistic = 3811.88, p < 0.001) and turtles were more active in daylight hours (Wald statistic = 194.85, $\mathrm{p}<0.001$ ). Dives during the day were not significantly shallower than dives at night (Wald statistic $=2.80, \mathrm{p}=0.095$ ).

At night 3 turtles rested in the lagoon and 2 rested on the reef. During the day, several activity patterns were observed: all day in the lagoon, all day on the reef and portions of the day in and outside the lagoon. Though the study duration was limited, some turtles were consistent in dive patterns while others were more variable (Fig. 6). Overall, however, while 3 of the 5 turtles spent much more time in the lagoon, all turtles made forays outside the lagoon to the reef, where they were susceptible to legal capture.

\section{DISCUSSION}

In the present study we combined a traditional capture-recapture method with deployment of TDRs, providing information on demography, distribution and diel movements of Caribbean green turtles. Size distribution suggests that the study area provides a developmental habitat for small juvenile to subadult turtles. While the number of recaptures in the present study was limited, mean growth rate was comparable to that found in other foraging grounds in the Caribbean and Bahamas (Boulon \& Frazer 1990, Bjorndal et al. 2000), suggesting a similar time to maturity. In the South Sound capture-recapture study, capture locations suggested fidelity to 

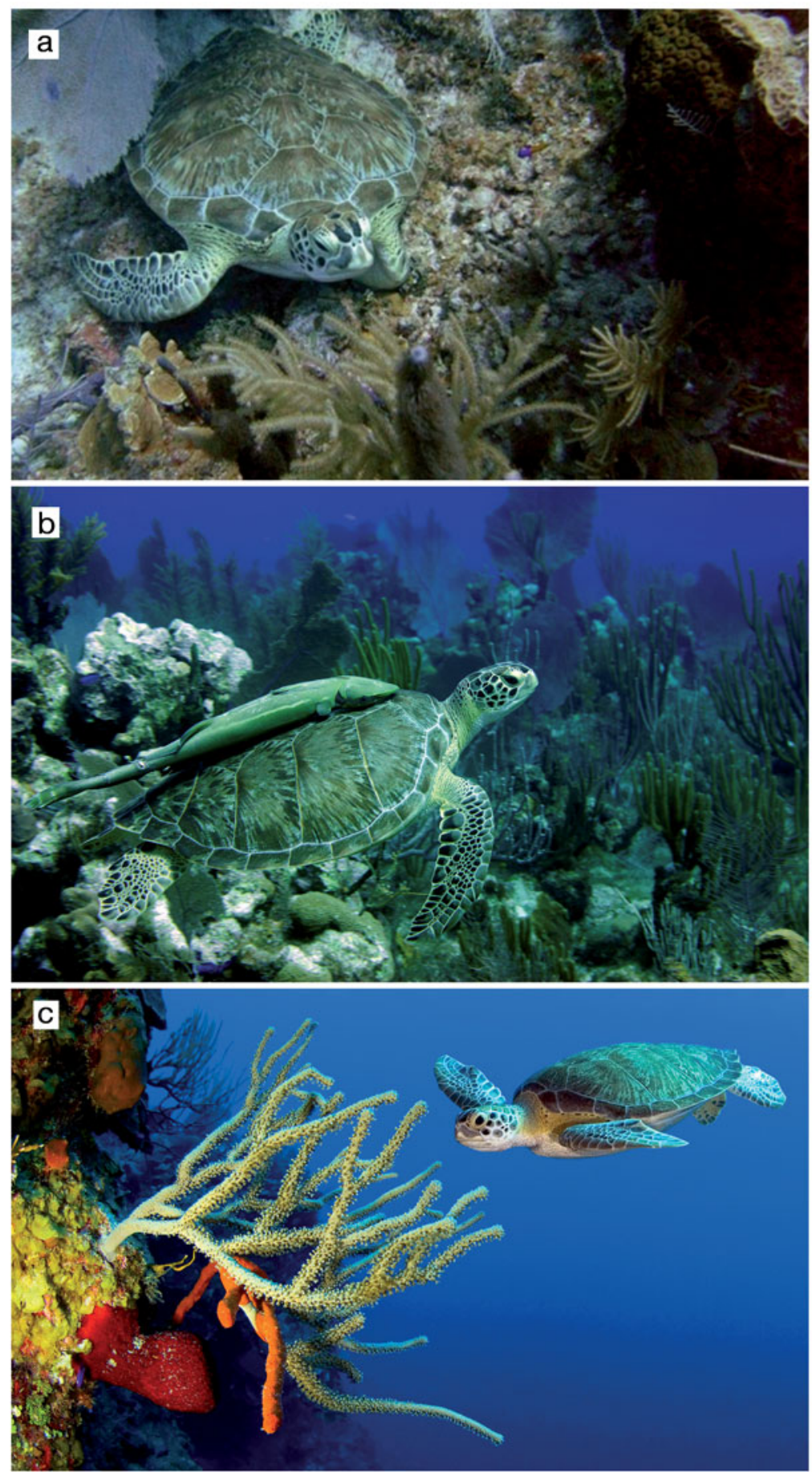

Fig. 5. Chelonia mydas. Cayman Islands green turtles outside the lagoon in (a) hard-bottom, (b) coral reef and (c) reef wall habitats

seagrass beds, the typical diurnal habitat of Caribbean green turtles based on previous studies (Mortimer 1981, Ogden et al. 1983). However, when turtles in the lagoon were instrumented with TDRs, we demonstrated that animals traveled through a narrow channel from the lagoon to the reef, often on a daily basis.
There are considerable difficulties associated with inferring activity from dive profiles (Seminoff et al. 2006, Blumenthal et al. 2009b), but for instrumented turtles in the Cayman Islands, dives at night were significantly longer and less active than diurnal dives, implying nocturnal resting. During the day, turtles were sighted on seagrass beds and sand patches in the lagoon, suggesting that both feeding and resting occurred. Diurnal excursions into deeper waters outside the lagoon could represent avoidance of predators or human disturbance (Seminoff et al. 2002), resting or thermoregulation (Mendonca 1983), visitation of cleaning stations (Losey et al. 1994), grazing algae (Musick \& Limpus 1997) or self-cleaning by rubbing against rocks and sponges (Heithaus et al. 2002). In the present study, TDRs recorded a decrease in temperature as turtles moved from the lagoon to the reef and, anecdotally, green turtles on reefs in the Cayman Islands have been observed at cleaning stations and rubbing against coral heads and sea fans Gorgonia spp. Turtles may have fed on algae in the reef environment, but an alternative method such as deployment of video-linked TDRs would be needed to confirm the occurrence of foraging behavior (Seminoff et al. 2006). Generally, while foraging ecology and the ecological role of green turtles on seagrass beds has been relatively well documented (Moran \& Bjorndal 2005), much remains to be determined regarding green turtles inhabiting or transiting through Caribbean coral reefs.

In addition to ecological implications, marine turtle distribution and local movement patterns may influence vulnerability to anthropogenic threats (McClellan \& Read 2009). In the South Sound lagoon, green turtle distribution showed a substantial overlap with human activity: captures in the lagoon were concentrated in a high use area between the channel and a public boat launching ramp, and turtles used a single, narrow route from the lagoon to the reef, increasing susceptibility to vessel collision, illegal harvest and incidental capture in hook and line fisheries (Department of Environment unpubl. data). Harvest of breeding turtles at a nesting beach can be unsustainable and may result in reduction or loss of the nesting population (McClenachan et al. 2006). Sim- 
Table 1. Chelonia mydas. Capture date, biometric data (straight carapace length [SCL], curved carapace length [CCL] and mass) and dive statistics (mean nocturnal and diurnal dive depth and duration) for instrumented turtles. One animal (Turtle 1) was not recaptured

\begin{tabular}{|c|c|c|c|c|c|c|c|c|}
\hline \multirow[t]{2}{*}{ ID } & \multirow{2}{*}{$\begin{array}{c}\text { Capture date } \\
\text { (2006) }\end{array}$} & \multirow[t]{2}{*}{$\mathrm{SCL}(\mathrm{cm})$} & \multirow[t]{2}{*}{$\mathrm{CCL}(\mathrm{cm})$} & \multirow[t]{2}{*}{ Mass (kg) } & \multicolumn{2}{|c|}{ Mean dive depth (m) } & \multicolumn{2}{|c|}{ Mean dive duration (min) } \\
\hline & & & & & Night & Day & Night & Day \\
\hline 1 & $6 \mathrm{Nov}$ & 49.9 & 52.7 & 15.7 & - & - & - & - \\
\hline 2 & $6 \mathrm{Nov}$ & 55.3 & 59.0 & 22.6 & 1.2 & 1.9 & 6.1 & 3.5 \\
\hline 3 & 7 Nov & 50.1 & 51.0 & 30.2 & 12.4 & 2.8 & 23.4 & 4.9 \\
\hline 4 & $7 \mathrm{Nov}$ & 53.9 & 59.0 & 23.3 & 7.6 & 1.8 & 18.1 & 3.8 \\
\hline 5 & $7 \mathrm{Nov}$ & 37.8 & 40.6 & 18.1 & 0.9 & 1.8 & 5.5 & 2.9 \\
\hline 6 & $7 \mathrm{Nov}$ & 52.2 & 54.9 & 15.5 & 1.4 & 2.0 & 6.5 & 3.8 \\
\hline
\end{tabular}

ilarly, overharvesting in a high vulnerability area (e.g. capture in a lagoon or netting in a channel) could have a high impact on juvenile foraging aggregations.

While quotas on legal take may represent a partial solution to overharvesting (Heppell et al. 2005), these are difficult to enforce. Given limitations in enforcement capability, our results highlight the potential importance of maintaining restrictions against marine turtle harvest in high-use areas and routes where overexploitation can easily occur. In the Cayman Islands,

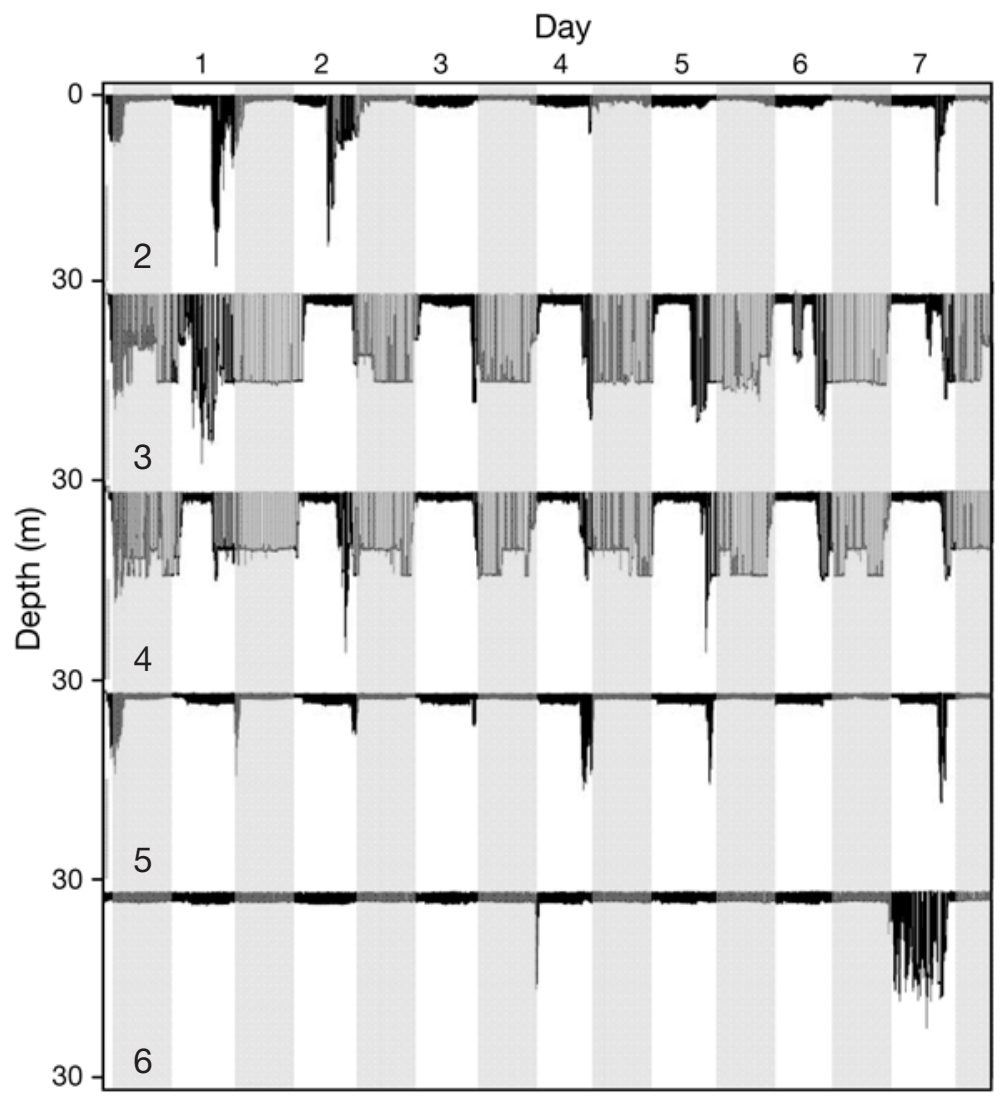

Fig. 6. Chelonia mydas. Dive profiles for Turtles 2 to 6 (Turtle 1 was not recaptured), showing movements from lagoon (less than $3 \mathrm{~m}$ depth) to reef (more than $3 \mathrm{~m}$ depth). Shading indicates night-time hours (sunset to sunrise) setting of fixed nets (used to capture turtles on routes such as channels from the lagoon to the reef) was banned in 2008 and a restriction on taking turtles within lagoons has been maintained. When area restrictions are implemented, however, it becomes necessary to determine how individuals and populations move across these boundaries. Our results showed that individuals frequently moved between protected and unprotected habitats, a finding which may have implications for management of other marine turtle foraging aggregations, particularly as other Caribbean jurisdictions implement maximum size limits for legal take. At present, the Cayman Islands is the only Caribbean jurisdiction with a maximum size limit, though 13 Caribbean countries and territories maintain some form of legal marine turtle harvest (Dow et al. 2007) and it is widely recognized that populations of long-lived, late-maturing species have difficulty supporting harvesting of subadult and adult individuals (Heppell et al. 2005).

It should be noted, however, that sample size, duration and geographic scope of the present study were limited. Also, in areas with unknown or more complex bathymetry, TDRs will be limited in their ability to resolve movements, and as dives are not always to the bottom, shallow dives cannot be assumed to have been made in shallow water. Nonetheless, as recorded dive depths in the present study frequently exceeded the depth of the water column inside the reef, we showed that turtles regularly left the protected lagoon and moved into unprotected habitats. This demonstrates that under certain circumstances, TDRs can provide a viable low-cost methodology for determining movements and exposure to threats.

In summary, capture-recapture methodology and integration of time-depth 
profiles and bathymetry proved a useful method for elucidating movements of marine turtles within a Caribbean foraging ground, indicating that turtles congregated in a high-use area in the lagoon, a channel from the lagoon to reef represented a high vulnerability habitat and movements beyond the boundaries of protected areas frequently occurred. Thus, we demonstrated that assessing daily movements may be an important component in revising fishery legislation, targeting law enforcement and managing protected areas and species.

Acknowledgements. For sharing the use of ultrasonic tracking equipment, we thank B. Semmens, S. and S. Heppell, L. Whalen, B. Johnson, P. Bush, C. McCoy, and K. Luke of the Grouper Moon Project, a collaborative effort between REEF and the Cayman Islands Department of Environment with funding provided by the NOAA International Coral Reef Conservation Program and PADI Project AWARE. We thank the following photographers for generously providing their images for Fig. 5: M. Braunstein, P. Weir (www.digitaldiver. biz) and K. and C. Alpers. For providing release data for the head-started green turtle, we thank J. Parsons and Cayman Turtle Farm. For assistance with fieldwork, we thank A. McGowan and L. Wright, and for logistical support, we thank Department of Environment administration, operations and enforcement staff. Work in the Cayman Islands and the UK was supported by the National Environment Research Council (NERC), the Darwin Initiative and the European Social Fund. We acknowledge support to J.M.B. (University of Exeter postgraduate studentship and the Darwin Initiative) and thank anonymous reviewers for input which improved the manuscript.

\section{LITERATURE CITED}

Balazs GH, Chaloupka C (2004) Spatial and temporal variability in somatic growth of green sea turtles (Chelonia mydas) resident in the Hawaiian Archipelago. Mar Biol 145:1043-1059

Bell CD, Blumenthal JM, Austin TJ, Solomon JL, EbanksPetrie G, Broderick AC, Godley BJ (2006) Traditional Caymanian fishery may impede local marine turtle population recovery. Endang Species Res 2:63-69

Bell CD, Solomon JL, Blumenthal JM, Austin TJ, EbanksPetrie G, Broderick AC, Godley BJ (2007) Monitoring and conservation of critically reduced marine turtle nesting populations: lessons from the Cayman Islands. Anim Conserv 10:39-47

Bjorndal KA, Bolten $\mathrm{AB}$ (1988) Growth rates of immature green turtles, Chelonia mydas, on feeding grounds in the southern Bahamas. Copeia 555-564

Bjorndal KA, Bolten AB, Chaloupka MY (2000) Green turtle somatic growth model: evidence for density dependence. Ecol Appl 10:269-282

Bjorndal KA, Bolten AB, Chaloupka MY (2003a) Survival probability estimates for immature green turtles Chelonia mydas in the Bahamas. Mar Ecol Prog Ser 252:273-281

Bjorndal KA, Bolten AB, Arenas A, Zurita J and others (2003b) Green turtle with a living tag captured in the southern Bahamas. Mar Turtle Newsl 101:26

Blumenthal JM, Solomon JL, Bell CD, Austin TJ and others (2006) Satellite tracking highlights the need for interna- tional cooperation in marine turtle management. Endang Species Res 2:51-61

Blumenthal JM, Austin TJ, Bell CDL, Bothwell JB and others (2009a) Ecology of hawksbill turtles Eretmochelys imbricata on a western Caribbean foraging ground. Chelonian Conserv Biol 8:1-10

> Blumenthal JM, Austin TJ, Bothwell JB, Broderick AC and others (2009b) Diving behavior and movements of juvenile hawksbill turtles Eretmochelys imbricata on a Caribbean coral reef. Coral Reefs 28:55-65

Bograd SJ, Block BA, Costa DP, Godley BJ (2010) Biologging technologies: new tools for conservation. Introduction. Endang Species Res 10:1-7

> Boulon RH, Frazer NB (1990) Growth of wild juvenile Caribbean green turtles, Chelonia mydas. J Herpetol 24:441-445

> Campbell CL, Lagueux CJ (2005) Survival probability estimates for large juvenile and adult green turtles (Chelonia mydas) exposed to an artisanal marine turtle fishery in the western Caribbean. Herpetologica 61:91-103

Cayman Islands Government (1985) The Marine Conservation (Turtle Protection) (Amendment) Regulations, 1985. Available at http://faolex.fao.org/docs/pdf/cay24166.pdf

Cayman Islands Government (2008) The Marine Conservation (Turtle Protection) (Amendment) Regulations (2008 revision). Available at www.gazettes.gov.ky

Chaloupka M, Limpus C, Miller J (2004) Green turtle somatic growth dynamics in a spatially disjunct Great Barrier Reef metapopulation. Coral Reefs 23:325-335

> Cooke SJ (2008) Biotelemetry and biologging in endangered species research and animal conservation: relevance to regional, national, and IUCN Red List threat assessments. Endang Species Res 4:165-185

Dow W, Eckert K, Palmer M, Kramer P (2007) An atlas of sea turtle nesting habitat for the wider Caribbean region. WIDECAST Technical Report No 6, Beaufort, NC

> Fuller WJ, Broderick AC, Phillips RA, Silk JRD, Godley BJ (2008) Utility of geolocating light loggers for indicating at-sea movements in sea turtles. Endang Species Res 4: 139-146

Godley BJ, Blumenthal JM, Broderick AC, Coyne MS, Godfrey $\mathrm{MH}$, Hawkes LA, Witt MJ (2008) Satellite tracking of sea turtles: Where have we been and where do we go next? Endang Species Res 4:3-22

Hays GC, Adams CR, Broderick AC, Godley BJ, Lucas DJ, Metcalfe JD, Prior AA (2000) The diving behaviour of green turtles at Ascension Island. Anim Behav 59:577-586

Heithaus MR, McLash JJ, Frid A, Lawrence MD, Marshall GJ (2002) Novel insights into green sea turtle behaviour using animal-borne video cameras. J Mar Biol Assoc UK 82: 1049-1050

Heppell SS, Heppell SA, Read AJ, Crowder LB (2005). Effects of fishing on long-lived marine organisms. In: Norse EA, Crowder LB (eds) Marine conservation biology: the science of maintaining the sea's biodiversity. Island Press, Washington, p 211-231

Lewis CB (1940) The Cayman Islands and marine turtle. In: Grant C (ed) The herpetology of the Cayman Islands. Bulletin of the Institute of Jamaica Science Series, Kingston, p 56-65

Lewison RL, Freeman SA, Crowder LB (2004) Quantifying the effects of fisheries on threatened species: the impact of pelagic longlines on loggerhead and leatherback sea turtles. Ecol Lett 7:221-231

Limpus CJ, Reed PC (1985) The green turtle, Chelonia mydas in Queensland: a preliminary description of the population structure in a coral reef feeding ground. In: Grigg G, Shine $\mathrm{R}$, Ehmann H (eds) Biology of Australasian frogs and rep- 
tiles. Royal Zoological Society of NSW, Sydney, p 47-52

Losey GS, Balazs GH, Privitera LA (1994) Cleaning symbiosis between the wrasse, Thalassoma duperry, and the green turtle, Chelonia mydas. Copeia 1994:684-690

McClellan CM, Read AJ (2009) Confronting the gauntlet: understanding incidental capture of green turtles through fine-scale movement studies. Endang Species Res 10: 165-179

McClenachan L, Jackson JBC, Newman MJH (2006) Conservation implications of historic sea turtle nesting beach loss. Front Ecol Environ 4:290-296

Mendonca MT (1983) Movements and feeding ecology of immature green turtles (Chelonia mydas) in a Florida lagoon. Copeia 1983:1013-1023

Moran KL, Bjorndal KA (2005) Simulated green turtle grazing affects structure and productivity of seagrass pastures. Mar Ecol Prog Ser 305:235-247

Mortimer JA (1981) The feeding ecology of the West Caribbean green turtle (Chelonia mydas) in Nicaragua. Biotropica 13:49-58

Musick JA, Limpus CJ (1997) Habitat utilization and migration in juvenile sea turtles. In: Lutz PL, Musick JA (eds) The biology of sea turtles. CRC Press, Boca Raton, FL, p 137-164

Ogden JC, Robinson L, Whitlock K, Daganhardt H, Cebula R (1983) Diel foraging patterns in juvenile green turtles (Chelonia mydas L.) in St. Croix United States Virgin Islands. J Exp Mar Biol Ecol 66:199-205

Richardson P, Broderick A, Campbell L, Godley B, Ranger S (2006) Marine turtle fisheries in the UK overseas territories of the Caribbean: domestic legislation and the requirements of multilateral agreements. J Int Wildl Law Policy 9:223-246

Ropert-Coudert Y, Beaulieu M, Hanuise N, Kato A (2009) Diving into the world of biologging. Endang Species Res 10:21-27

Schofield G, Bishop CM, MacLean G, Brown P and others (2007) Novel GPS tracking of sea turtles as a tool for conservation management. J Exp Mar Biol Ecol 347:58-68

Schofield G, Lilley MKS, Bishop CM, Brown P and others

Editorial responsibility: Brent Stewart,

San Diego, California, USA
(2009) Conservation hotspots: implications of intense spatial area use by breeding male and female loggerheads at the Mediterranean's largest rookery. Endang Species Res 10:191-202

Seminoff JA, Resendiz A, Nichols WJ (2002) Home range of green turtles Chelonia mydas at a coastal foraging area in the Gulf of California, Mexico. Mar Ecol Prog Ser 242: $253-265$

Seminoff JA, Jones TT, Marshall GJ (2006) Underwater behaviour of green turtles monitored with video-timedepth recorders: What's missing from dive profiles? Mar Ecol Prog Ser 322:269-280

Storch S (2003) The behaviour of immature and female hawksbill turtle (Eretmochelys imbricata) at sea. PhD thesis, Kiel University, Kiel

$>$ Taquet C, Taquet M, Dempster T, Soria M, Ciccione S, Roos D, Dagorn L (2006) Foraging of the green sea turtle Chelonia mydas on seagrass beds at Mayotte Island (Indian Ocean), determined by acoustic transmitters. Mar Ecol Prog Ser 306:295-302

Troëng S, Evans DR, Harrison E, Lagueux CJ (2005) Migration of green turtles Chelonia mydas from Tortuguero, Costa Rica. Mar Biol 148:435-447

van Dam RP, Diez CE (1996) Diving behavior of immature hawksbills (Eretmochelys imbricata) in a Caribbean cliffwall habitat. Mar Biol 127:171-178

van Dam RP, Diez CE (1998) Home range of immature hawksbill turtles (Eretmochelys imbricata (Linnaeus)) at two Caribbean islands. J Exp Mar Biol Ecol 220:15-24

Wilson RP, Shepard ELC, Liebsch N (2008) Prying into the intimate details of animal lives: use of a daily diary on animals. Endang Species Res 4:123-137

Wood FF, Wood JR (1993) Sea turtles of the Cayman Islands. In: Brunt MA, Davies JE (eds) The Cayman Islands: natural history and biogeography. Kluwer Academic Publishers, Dordrecht

Zbinden JA, Aebischer A, Margaritoulis D, Arlettaz R (2007) Insights into the management of sea turtle internesting area through satellite telemetry. Biol Conserv 137: $157-162$

Submitted: July 10, 2009; Accepted: January 11, 2010 Proofs received from author(s): March 31, 2010 